\title{
RESEARCH
}

\section{Critical Belonging: Cohabitation, Plurality, and Critique in Butler's Parting Ways}

\author{
Miri Rozmarin \\ Gender Studies Program, Bar-Ilan University, IL \\ mirirozmarin@gmail.com
}

This article engages Judith Butler's Parting Ways as a way to rethink the relations between critique and belonging as two aspects of contemporary political subjectivities. I argue that for Butler critique is an action performed by corporeal subjects. As such, it depends on cohabitation being an ontological condition. Belonging, in the sense of sharing a place with others, assesses an affirmative stance - the commitment to safeguard the common conditions for a plurality of lives.

The first part of the article regards Butler's theorization of cohabitation and plurality as a framework in which the corporeal and embodied relations with others who share a place serve as a condition for critique rather than its limit. I argue that Butler's Arendtian social ontology aims to offer a vision of political subjectivity that differs from contemporary forms of subjectivation. I further argue that in order to promote such vision of political subjectivity, a detailed description of cohabitation is required as a multi-layered affective and emotional relation with one's surroundings.

The second part of the article focuses on how Butler performs in her text this alternative vision of political subjectivity that affirms pluralization as a normative principle. By studying Butler's account of her Jewishness as well as textual practices shaping the text, I argue that belonging can become a formative aspect of the critical subject through the acts of norms on one's body as well as by critical engagement.

Keywords: Critique; belonging; cohabitation; plurality; corporeality; Judith Butler

\section{Introduction}

The relations between critique and belonging are a pressing issue. This alleged contradiction delegitimizes critique by regarding it as a sign of disloyalty and sabotage. Nevertheless, people worldwide participate in mass protests that mobilize a sense of lost belonging - or being robbed of their place - and reclaim their land, country, or state. Many others who leave their homelands are denied any conditions of belonging in their new places. Their status as illegal immigrants denies them access to the position of a political subject. Some populist political discourses in contemporary politics present critique as a hostile and illegitimate form of political participation. In various contemporary critical and activist communities, 
the question concerning the relations between critique and belonging usually focuses on the conditions of participation in the political community and performing critique. For example, are any normative conditions required to be termed a feminist? Is it possible to critique the norms or practices of certain groups without being part of them?

In this context, it is crucial to analyze the relations between critique and belonging and study how these two notions can be considered two aspects of the lives of political subjects. This perspective focuses on how critique, as a political act, is conditioned by other aspects of subjects as they engage politically with their social world and how it interacts with these aspects.

The act of critique, as was formulated by the Frankfurt school, aims to deconstruct the internal consistency of ideological mechanisms (Adorno 1973, XX; Horkheimer 2004). Although the notion of critique assumes both a negative stance, which aims to denaturalize ideological representations of social reality, and an affirmative stance, which advances an alternative world that is more just, the development of critical thinking emphasized the negative stance and undermined the affirmative one. The main role of critique is unmasking the forms of domination and injustice that lie behind the ideological scripts of everyday life. Rebughini $(2018,8)$ argues that:

Critique is a self-reflexive continuous search for possible complicities with power, common sense, self-evidence, or status quo interests. It has to resist domination but also itself; it has to be vigilant concerning the present and not solely critical of what has already happened.

Rebughini $(2018,7)$ further argues that in this theoretical framework, "critical agency stems from a refusal to adapt oneself.' Critical subjectivity, thus, assumes the possibility and epistemological advantage of radical separation from the mainstream outlook of day-to-day reality. The relations of critical subjects with the objects of their critique depend on disavowing the relational and corporeal dimensions of these relations.

The image of critique as an action of getting 'out of the matrix' creates a dichotomous political discourse in which one is part of either the problem or the solution. In this framework, criticizing the collective to which one belongs should not be a complex and conflicting experience. If it is, this complexity should at least not interfere with the negation of the apparent reality being criticized.

Moreover, this dichotomous framework presents a permanent risk of disintegrating critical communities and groups since the critical subject is primarily committed to detecting complex and subtler forms of oppressive structure, due to which ambivalence or attachments to one's aspects of everyday life can be regarded as an indication of being a political rival.

Postcolonial scholars have argued that critique is associated with the European subject, and thus have radically questioned the basic normative presuppositions of critical theory (Asad 2003; Mahmood 2005; Mahmood 2006). Mahmood argues that the Kantian tradition associates ethical agency with rational judgement, which aims to transcend specific cultural contexts and personal conditions. Western legacy pays insufficient attention to the ways in which practices, habits, and emotional expressions manifest in the active positioning of political subjects in relation to norms and institutions (Mahmood 2003, 845-46).

However, Mahmood's account of political agency downplays the critique aspect. Although she stresses that political agency can result from performing traditional and religious practices, she does not conceptualize the possibility of critique being part of this post-secular political subjectivity. Therefore, the relations between belonging to a community, a people, a family, or a place and being critical of these frames of belonging lack sufficient theorization. 
What may seem as a crisis and a decline in the social and theoretical appeal of critical theory has led several prominent thinkers to defend the general project of critique and its social importance emphatically by reformulating its basic concepts in ways that address postcolonial critique (Allen 2016; Jaeggi 2018; McNay 2014). This article aims to contribute to this general political and theoretical effort of rethinking the notion of critique in order to render it effective and relevant to contemporary reality. It does so by rethinking the fundamental image of the critical act as part of the life of political subjects, as in Judith Butler's Parting Ways. I will argue that Butler's critical argument and the ontology of cohabitation it draws from entails a promising account of the critical subject - one that might overcome some of the difficulties that characterize contemporary critical discourses.

Belonging is a complex and multifaceted relationship between people and their surroundings. There are distinct forms of spatio-temporal belonging - namely, to a country, a place, a generation, a tradition, or a political group. Some of these forms of belonging are voluntary, whereas others are not. Although belonging has clear emotional and psychological aspects, it is also a cultural and social fact about the physical location and connections of people. It is conditioned by power formation, which shapes national, ethnic, racial, gendered, or religious identities. However, as Yuval-Davis et al. $(2006,1)$ argue,

it is impossible to understand the ways individual people and groupings relate to and are being treated by both state and society these days just by being related to as either citizens and/or having specific ethnic, national, or racial identities. Politics of belonging encompass and relate both citizenship and identity, adding an emotional dimension, which is central to notions of belonging.

This article does not attempt to answer 'What is belonging?' Instead, it constructs a notion of belonging from Butler's Parting Ways to illuminate how belonging and critique interact and shape political subjects. I focus on this text because of what I argue are the distinct relations between critique and belonging that are discussed in the book while shaping its rhetoric.

Butler's Parting Ways is clearly a critical project. It shares with the previous and later works of Butler the commitment to destabilize the power formations that produce hegemonic normative orders. It is also part of her continual critique of Zionism and her critical engagement with the Israeli occupation of the West Bank and Gaza. Over the years, Butler has offered a critical analysis of the connections between the political narrative of Zionism and its account of Jewish nationalism and the continual deprivation of human rights of the Palestinians. However, Parting Ways is a unique endeavour within this continual critical project. It is primarily a creative political endeavour to recreate a pre-Zionist and non-Zionist political Jewish subject. As such, it attempts to present an alternative cultural narrative through which one can be a Jewish political subject while rejecting the Zionist narrative as a justification of the violent logic of the relation with the Palestinians. This new critical subject is made possible through a web of relations with ideas, people, and texts, through which this alternative interpretation of reality and dispositions to react are offered.

For this reason, this article presents Butler's notion of critique and belonging as presented through her engagement with the works of Hannah Arendt. Rather than distinguishing between Butler and Arendt's arguments, this article attempts to preserve the textual relational space between them as a crucial feature of the political subjectivity emerging from the text. ${ }^{1}$

\footnotetext{
1 Butler's intellectual engagement with Arendt encompasses almost two decades. The relations between the works of these two scholars are complex. Some of the affinities between the two are clear. Both scholars strive to
} 


\section{Butler - Critique, Norms, and the Corporeal Subject}

In her earlier work, Butler embraced an externalist critical analysis of micro-power as it works on bodies to constitute subjects. In Bodies That Matter, she associates the process of becoming a subject with being subjected to the norms through repetitive performative practices. Butler stresses that norms have a constitutive through which the materiality of sex is produced. Through repetitive practices, bodies become intelligible embodied subjects (1993, 29-31). In this process, primary bodily attachments and sensations are shaped by norms, while leaving affective 'residues' that exist beyond the grasp of the subject's narrative or coherent identity (Butler 2001, 27). Butler's work in this regard mainly offers a negative critique of power formations, revealing the contingent nature of what may appear as natural or given.

In later works, Butler argues that the individual's submission to normative power formation is not merely a mechanistic process of powers, but rather a passionate process driven by a desire to continue to exist, which propels the submission to interpellation as a way of being part of society.

These passionate attachments serve as an affective resource unexhausted by specific interpellations for 'critical desubjectivation' (Butler 1997, 130). In these texts, critique is closely connected to a strategic de-subjectivation that aims to negate the alleged natural status of normative identities and subject formations. Carolyn Culbertson argues that in these writings, Butler's critique depends on the normative context in which it appears, which affects the intelligibility of the critical subject $(2013,451)$.

I agree with Culbertson that for Butler, the critical subject depends on the normative order to become an intelligible subject and that in this sense, critique as a practice always depends on others. However, the fact that one belongs to a certain community or group or associates oneself with an identity category, and is thus dependent on normative practices functions as a limit of critique, not as one of its productive aspects.

Butler's later work on vulnerability offers a comprehensive ontological background of critical subjects. Butler introduces the notion of vulnerability as a conceptual framework that aims to expand the performative theory to account for the normative production of the 'Human.' Butler argues that vulnerability is a condition inherent to life (Butler 2004a, 31).

The primary source of vulnerability is the social and corporeal relationality of subjectivity (Butler 2004a, 20). As a relational subject, one depends on others to sustain one's life and humanity. However, one's relations with others are governed by normative practices that frame the boundaries of whose life is livable and significant (Butler \& Athanasiou 2013, 4). Hence, although vulnerability is a shared ontological feature as actualized by concrete power formation, the map of vulnerabilities is diverse and connected to an intersectional map of power.

Vulnerability appears as two distinct and opposing sets of subjective experience. On the one hand, vulnerability appears as an experience of dispossession, which radically interferes with the subject's self-image as an autonomous, self-sustained unit (Butler \& Athanasiou 2013, 11). On the other hand, the subject's relations with the other open the subject to the world in ways that enrich one's life (Butler 2004b, 19). An 'other' introduces elements that drive the

engage with their social reality, respond to emerging conditions, and interfere by offering critical theorizations (Pulkkinen 2018; Kellogg 2018, 360).

However, some scholars have highlighted the aspects of Butler's reading of Arendt that are debatable and, as they argue, are either unfaithful to Arendt's texts (Lederman 2020; Birmingham 2018) or are not truly Arenditian (Loidolt 2018, 9; Pulkkinen 2018). In some places, Butler declares that her strategy is reading Arendt against herself' (Butler \& Chakravorty 2007, 27). 
subject to go beyond a certain sense of identity and act in ways that surpass any attempt at self-determination. In this respect, vulnerability appears as an exposure of the limits of one's own narrative and knowledge, and presents the possibility of something radically new.

Butler presents her account of the body as the basis for political action. She argues,

We cannot talk about a body without knowing what supports that body, and what its relation to that support-or lack of support-might be. In this way, the body is less an entity than a living set of relations; the body cannot be fully dissociated from the infrastructural and environmental conditions of its living and acting. $(2015,65)$

Butler thus anchors a normative framework based on this account of corporeal subjectivity, which aims to 'forge a set of bonds and alliances to link interdependency to the principle of equal value, and to do so in a way that opposes these powers that differentially allocate recognizability, or that disrupts its taken-for-granted operation' $(2015,43)$.

Butler published Parting Ways in 2012 as part of this wider conceptual framework. The book critiques Zionism as a political project that considers itself the only ethical solution for the Jewish people's political existence. The book also articulates the possibility of a different Jewish subject, one that acknowledges its Jewish belonging while realizing a critical position regarding the Zionist political project. The book, as Klee and Topolski argue, not only argues for the ethics of cohabitation, it also performs a diasporic mode of thinking, here conceived as a textual methodology, a hermeneutics, and a broader sensibility for approaching contemporary ethical and political questions' $(2020,237)$. It is thus a productive source for rethinking the relations between critique and belonging to a political cultural collective.

\section{Belonging, Cohabitation, and Plurality}

In Parting Ways, Butler's notion of belonging rests on two related concepts - namely, cohabitation and plurality. Butler follows Arendt in asserting that as corporeal beings, we are born in a place that serves as a primary material resource for our basic needs. From the beginning, people share a place with others and depend on their support to participate in social life and realize their humanity.

Arendt acknowledges that cohabitation is not only a material dependency protected by rights, but also a multi-layered affective and emotional relationship that shapes a sense of distinct self. She writes:

The first loss which the rightless suffered was the loss of their homes, and this meant the loss of the entire social texture into which they were born and in which they established for themselves a distinct place in the world. (Arendt 1951, 293)

Arendt argues that belonging to a place is the precondition of other rights. Belonging means being part of a community in which one's actions and opinions are significant and affective (Arendt 1951, 296). Butler $(2012,147)$ interprets Arendt's famous characterization of belonging as 'the right to have rights' as referring to the necessity of both corporeal support and political belonging.

Butler argues that the physical place is endowed with political relationships, which shape the conditions under which people can appear as subjects. She echoes her performative theory, writing,

'No one body establishes the space of appearance, but this action, this performative exercise, happens only "between" bodies, in a space that constitutes the gap between 
my own body and another's. In this way, my body does not act alone when it acts politically. Indeed, the action emerges from the "between," a spatial figure for a relation that both binds and differentiates.' (Butler 2015, 77)

Thus, Butler stresses that cohabitation precedes the formation of the subject's choice and will. As corporeal creatures, our life is granted to us by others and it is conditioned by norms and institutions that influence the condition of livability significantly.

Following this relational logic, Butler also argues that the concept of cohabitation aims to challenge the understanding of what a political collective is and the association of collectives with a self-sustained spatio-temporal presence.

The co of cohabitation cannot be thought simply as spatial neighborliness: there is no home without adjacency, without a line that demarcates and binds one territory to another and so no way to reside anywhere delimited without the outside defining the space of inhabitation. The co of cohabitation is also the nexus where convergent temporalities articulate present time, not a time in which one history of suffering negates another, but when it remains possible that one history of suffering provides the conditions of attunement to another such history and that whatever connections are made proceed through the difficulty of translation. (Butler 2012, 130)

Therefore, cohabitation does not simply mean a state in which individuals are willing to accept the presence and rights of others. Instead, it conceptualizes the space people share as being embedded in cultural meanings, histories, and material sediments of past generations. Marking one's home is always in relation to the others who are there, and it is only in relations to others that individuals or groups can appear (Butler 2012, 130).

The cohabitation of the earth with others means that plurality is a basic ontological fact about human lives. As Arendt (1958, 7) stresses: 'men, not Man, live on the earth and inhabit the world.' In The Life of the Mind, Arendt argues that plurality stems from the nature of sensate being as being meant to appear 'in other words, nothing that is, insofar as it appears, exists in the singular; everything that is is meant to be perceived by somebody' $(1971,19)$.

Birmingham $(2018,331)$ argues that for Arendt, the human sense of reality depends on this sensuous world of appearances shared in common with a plurality of other beings. Appearance for Arendt, stresses Pulkkinen (2018), is a key concept that points to the ontology of phenomenal subject. 'Appearing relates, instead, to something that is often also called transcendental consciousness, as that which constitutes, for us, that which is/appears to us (Pulkkinen 2018, 134).

As stemming from the ontological condition of appearance, plurality, for Arendt, is a condition for thinking, action, and politics. By acting, we actualize who we are with others and who we are in relation to them (1971).

Butler draws on Arendt's conception of plurality and conceptualizes it as both an ontological condition for life and an ethical principle. As an ontological condition, we are part of a world inhabited by many different living beings, human and non-human. People belong to different collectives based on nationality, religion, race, and so on. They hold different beliefs and wishes, perform different practices, and have different capabilities.

Following Arendt, Butler proposes that plurality is a condition for action in the social sphere, through which people can actualize their humanity. She also draws on Arendt when she argues that plurality is a condition not only for action but also for thinking itself. Even thinking in solitude is addressed to others and reveals the relationality of the subject (Butler 2012, 173). 
However, when Butler stresses that plurality is realized through language, for her language is a performative field governed by the reiteration of norms. As thinking involves language, it is always conditioned by norms that bind the individual to others.

Butler follows Arendt in stressing that in social spaces that dictate unanimous thinking, freedom cannot be performed and people's subjectivities cannot be actualized (Butler 2012, 171). In such places, an increasing number of people are not recognized as subjects, and this dehumanization can easily devolve into genocide (Butler 2012, 171).

Both Butler and Arendt believe that cohabitation and plurality are ontological aspects of human lives. Yet, they acknowledge that people can live and act in conflict with these ontological conditions (Arendt 1958, 10-11; Butler 2012). Hence, the turn to ontology does not simply aim to identify some binding conditions for all human existence. Butler follows Arendt in turning to ontology in order to offer an alternative normative horizon, one that provides a new account of life and humanity (Butler \& Athanasiou 2013, 122). Butler makes this normative turn with Arendt:

If Arendt is right, then it is not only that we may not choose with whom to cohabit, but that we must actively preserve and affirm the unchosen character of inclusive and plural cohabitation: we not only live with those we never chose and to whom we may feel no social sense of belonging, but we are also obligated to preserve those lives and the plurality of which they form a part. In this sense, concrete political norms and ethical prescriptions emerge from the unchosen character of these modes of cohabitation. $(2012,25)$

Butler articulates cohabitation and plurality as ontological conditions of social bodies in order to promote a vision of social relations in which dependency, vulnerability, and plurality do not serve as a motivation for violence, but instead possibly yield a political subjectivity whose "history of suffering provides the conditions of attunement to another such history, and [...] whatever connections are made proceed through the difficulty of translation' (Butler 2012, 130).

The turn to ontology enables the critique of systematic forms of social injustice and violence, disregarding their ideological justifications. Thus, plurality and cohabitation serve as an ethical anchor and a normative guideline in relation to which critique is performed. Plurality as a normative principle means that as acting beings, we are committed to address the other and safeguard the appearance of others in the social realm as acting, thinking subjects. Butler follows Arendt in asserting that when groups and individuals attempt to choose and determine with whom they will share the earth, they violate the most basic condition of human life, and that these attempts thus serve as the primal principle of genocide (Butler 2012, 125). Plurality dictates that there can be no set of pre-conditions determining who is permitted to participate in the political and social sphere as a free subject (Butler 2012, 126). Thus, plurality is a multiple and continual process of pluralization. Therefore, the ethical commitment is to 'making new modes of pluralization possible' (Butler 2012, 126).

Accepting plurality as a basic principle does not lead to the eradication of communities that are based on shared heritage, beliefs, or rituals. On the contrary, Butler argues that pluralization assumes the existence of different communities with differentiating principles that distinguish between 'them' and 'us.' However, she stresses that from the perspective of cohabitation, these groups are not independent, self-defining entities. Instead, they are implicated in one another through complex spatio-temporal entanglements (Butler 2012, 127). 


\section{The Affective and Emotional Aspects of Cohabitation}

Butler and Arendt's notion of cohabitation aims to offer an image of belonging that is an alternative to the association of belonging with home as a territory one masters and owns. Butler acknowledges that the phantasy of being a self-determining master of one's life might be 'a source of a great range of emotional consequences from desire to hostility or, indeed, some combination of the two' (Butler 2012, 176). In relation to current nationalistic and neoliberal forms of governmentalities, the experience of cohabitation and plurality is associated with vulnerability and can contradict the image of the ideal autonomous, independent, and resilient human subject. Indeed, as in the Israeli-Palestinian example discussed by Butler, an awareness of different historical narratives and temporalities entangled around one place may lead to attempts to eradicate and delegitimize the other's narrative.

The inability of the ontology of cohabitation to determine people's actions is taken to be a pitfall of Butler's political theory. Benhabib argues that Butler's ontology fails to offer a normative guideline since it fails to integrate the demand to respond to the particular other with the need to take into account the 'generalized other' $(2018,85)$.

As mentioned before, both Butler and Arendt agree that although cohabitation and plurality are embedded in people's most basic condition of natality and corporeality, they do not compel people to act in accordance with them. Thus, in order for Butler's vision of political subjectivity to be a productive and effective alternative to contemporary forms of subjectivation, it is important to offer a comprehensive description of cohabitation as a multi-layered affective and emotional relationship with one's surroundings. Such a description can illustrate cohabitation as an emotional and affective resource that can counter the affective and emotional relations produced by nationalistic discourses.

Butler acknowledges that cohabitation is not just a political principle, but is an actual day-to-day situation in which people find themselves in the context of proximity or conflict, which is interrupted or signified by the memories, suffering, or longing of someone else (Butler 2012, 130). Moreover, she stresses that:

If we think of cohabitation only as a political goal, but not as a condition of social existence, then we fail to understand not just the agonism implied by unchosen cohabitation, but the longing, the dependency, the constraint, the possibilities for encroachment, impingement, and displacement. $(2012,176)$

Nevertheless, Butler takes this insight to mean that conditions of food security and other material needs should be emphasized as aspects of cohabitation. I would like to suggest that since cohabitation should be understood as an aspect of the everyday lives of people, it follows that we should think about cohabitation as an everyday practical sense of belonging to a place one shares with others. To do that we have to think about cohabitation as an intimate and multi-layered affective and emotional relationship with the place one shares with others. Belonging is embodied (Askins 2016). As Butler's discussion demonstrates, everyday interactions highlight how belonging rests on imagined geographies that are created through power, language, politics, and history, as well as the everyday relational encounter with one's surroundings. Kohl (2020) argues that place-based identities can become a site for a conscious political articulation of identity that goes beyond lines of exclusion and othering, and present an intersectional conception of belonging.

In order to offer a politically effective alternative that can interfere with politics, which uses the notion of belonging through the phantasy of home being a property one owns, we should think about the alternative notion of belonging beyond the exclusionary idea of a home. A non-excluding notion of belonging should rest on the corporeal aspects of affective ties, sights, smells, sounds, and emotional attachment, which accompany personal memories, 
habits, and traditions. As an affective and emotional resource, these affective ties can affirm plurality beyond the normative mechanisms that aim to erase the meaningfulness of such cohabitation. It can concretize, as a significant experience, the fact that the other who shares the space is not an abstract threat.

In the last chapter of the book, Butler seems to acknowledge the importance of the affective aspects of her political vision of cohabitation in her discussion of the possibility of a just political reality in Israel/Palestine that is based on cohabitation. Drawing on Edward Said and the Palestinian poet Mahmood Darwish, she discusses the option that Jewish and Palestinian histories of exile can intertwine and disrupt the constitution of authoritative and exclusionary narratives of identity $(2012,214)$. Looking at how the identities are bound with the practices of colonialism, she wonders in despair how is it possible these identities and experiences can exceed the logic of occupation (2012, 214-15). Nevertheless, she turns to Darwish as someone who gave voice to the conditions of unwilled proximity, and how these conditions could create 'something else' $(2012,217)$. Butler looks toward Darwish for the resources for hope as a political force that may enable a transformation of the political reality in Israel/ Palestine. As per her reading of Darwish, speech cannot give hope; instead, speech needs hope. Moreover, the resource for hope is a scream. She quotes Darwish who writes, 'And scream that you may hear yourself,/and scream that you may know you're alive,/and alive, and that life on this earth is possible'2 $(2012,219)$. I would like to suggest that this turn to the scream beyond language as a message of life, a life in the present as well as a life to come, is an acknowledgement of the importance of the affective forces of life as being crucial in motivating the political subject to struggle for a more just world.

Arendt's sense of cohabitation may suggest a different and more direct path of accounting for the affective aspects of belonging. For Arendt, cohabitation is grounded in the ontological event of natality, which, Birmingham $(2018,332)$ argues, is a notion of the primordial sensus communis of embodied subjects at the level of appearance. However, as Pulkkinen (2018, 139-41) argues, Butler's account of cohabitation dissociates corporeal singularity and relationality, stressing the norm-governed and social nature of plurality while undermining the primary corporeal relations with the maternal body. It could be that this undermining of primary corporeality leads Butler to mark the sensuous, affective, and emotional relations with one's place as a plurality of colors, tastes, landscapes, and sounds that constitute one's sense of origins and place in the world with others as an invention-a miraculous force that aims to realize the impossible $(2012,222)$.

The affective aspect in Butler's discussion serves to introduce an affirmative force that introduces hope as a political emotion. Without this affirmative horizon, the critique of power seems to exclude the possibility of change. It is also an affective resource that can counter fear and rage, which are mobilized by violent discourses and practices. I suggest in the next section that this affective aspect of belonging to places and people that one shares with others does not only function as an affirmative element that transcends the effects of negative critique but also inspire and enable new modes of critique.

\section{Being the People to Come - Performance of Plurality and the Critical Subject}

Parting Ways has a clear and distinctive performative aspect. Butler does not only present an argument against Zionism and propose an alternative ethical tradition within Jewish thought, she also shapes the text in ways that introduce a new kind of political subject, one that performs the logic of plurality she promotes. Therefore, in order to elucidate the relations

\footnotetext{
${ }^{2}$ This quote is from: Mahmood, Darwish. 'Edward Said: A Contrapuntal Reading,' trans. Mona Anis,' Cultural Critique 67 (2007): 175-182.
} 
between critique and belonging further, I look at how the text performs political subjectivity as well as how Butler posits her critique in relation to her own Jewishness.

In her discussion of Arendt's Eichmann in Jerusalem, Butler notes that there are moments in the text that are populated with many voices and perspectives. Arendt, a German, a Jew, and a refugee who fled Nazi Germany, differentiated herself from the Zionist nation-state, which was the prosecutor in this trial, and interpreted the events of the trial and the conditions that enabled Eichmann to carry out genocidal crimes by voicing different reactions and positions in relation to Eichmann's testimony (Butler 2012, 15-56). Arendt refers to Eichmann and tries to articulate his way of understanding his deeds. At times, she also argues with him and voices the court's verdict and her own alternative verdict.

Butler argues that this textual form creates a plural, incoherent, and dynamic critical voice, which is the realization of the political subject of plurality (Butler 2012, 169). She also explicitly acknowledges the performative and creative aspect of this textual form when she writes that Arendt's writing 'casts the dialogic encounter within the self as an active and performative dimension of self-making' (Butler 2012, 170). However, she stresses that Arendt's dialogic writing emphasizes that:

No one constitutes him or herself in a social vacuum. Although this precept is sometimes strained by what Arendt occasionally says about the solitary character of thinking, sometimes it is not, especially when thinking is understood as speaking, and speaking is a performative act of some kind. (Butler 2012, 169).

Catherine Kellogg notes that Butler's tone in Parting Ways is reflexive and conversational. Kellogg $(2018,362)$ argues that this reflexive tone echoes Arendt and Butler's thesis that reflexivity is invoked by plurality of voices, which is the condition for politics. Indeed, Butler develops her argument by engaging with other Jewish philosophers, among whom are Arendt, Walter Benjamin, and Emanuel Levinas. Her readings assemble Jewish heritage, with which she affirms a possibility to think politically beyond and against the logic of a Jewish nation-state within Jewish traditions.

Butler not only draws on Jewish thinkers, she also characterizes her critique as 'Jewish critique' (Butler 2012, 1) and presents plurality and cohabitation as 'Jewish values' (Butler 2012, 116). By positioning her critique and moral theory as Jewish, Butler does not intend to limit the applicability or relevance of the ethics she suggests to Jewish people. Rather, she performs the possibility to be part of the Jewish people while criticizing Zionism as their only political realization. She thus constitutes an alternative Jewish political subject who draws different political conclusions and ethical commitments from the history of the Jewish people. This political subject serves as an alternative to the Zionist normative claim for the ideals of resilience, autonomy, and self-determination.

Following her assertion that belonging to a collective shapes the process of subject formation, Butler acknowledges that her own textual subjectivity is shaped by collective historical aspects and religious embodied practices, which she cannot fully account for or separate from herself (Butler 2012, 22). She acknowledges that the resources with which she formulates her critique are also shared by her opponents - namely, Zionists. Sharing cultural embodied formations with people she fiercely opposes, some of them consider her an enemy, creates a continual dynamic of disorientation for her and reorients her position as a critical subject (Butler 2012, 22). Nevertheless, situating critique in relation to these formative experiences becomes a practice through which one can shape new options of living as part of this collective. She writes: 
The text is skewed by my own formation, but it means to document what can and must be done with one's own formation, how it must be repeated in new ways, and where a departure from formation becomes ethically and politically obligatory (for reasons both internal and external to that very formation). This, then: my symptom, my error, my hope .... (Butler 2012, 27)

Thus, rather than stemming from a unified coherent position, critique here is a continual action nourished by cultural experiences and practices that are shared with those who one aims to critique. By criticizing Zionism, Butler's textual persona re-signifies aspects of her own formation - namely, her memories, community, and history. Critique becomes a transformative process for the critical subject.

Here, Jewishness functions as a collective emotional and cultural resource that supports the actualization of the radical alternative to Zionism promoted by Butler $(2012,2-3)$. The intellectual history she summons affirms the Jewish desire to persist as a social and political collective, which is, above all, a 'living plurality of beings' $(2012,136){ }^{3}$

However, the text presents an additional relationship between the critical subject and belonging beyond the creative and affirmative stance of Butler's belonging to the Jewish people. Following Arendt, Butler stresses that belonging to the Jewish people is not a matter of choice (Butler 2012, 133). It is not a matter of identification with some abstract entity or love of it either. Butler interprets Arendt, who describes her Jewishness as a physei, a natural fact about her existence. However, Butler rejects a clear distinction between physei and nomos, nature and habit. She argues that Arendt's terming of her Jewishness as physei is an act of the cultural crafting of her physicality (Butler 2012, 134). Butler writes that for Arendt, this cultural crafting of belonging is partly because she positions it as a standpoint from which she conceptualizes her political theory. Arendt's experience as a German Jew in Nazi Germany yielded the political sensibility and obligation to oppose mechanisms of national violence against populations (Butler 2012, 135).

Butler does not elaborate on the process of crafting one's own physei, and does not elucidate how this interplay between the factual pre-subjective aspects and creative actions constitutes a political subject as belonging to a group. If we take Arendt and Butler as examples, there is a crucial difference between the two. It is reasonable to assume that, for Arendt, Jewishness became inscribed as part of her physical existence at least partially because she was marked as a Jew by her surroundings - not as a result of her actions but her lineage. As a result, she was affected throughout her social life and eventually had to escape Germany and become a refugee. Arendt's story exemplifies how belonging is imprinted on one's body through violent and abusive normative practices beyond the subject's choice. However, Butler is an example of a different process of how belonging becomes part of one's physicality. I would not like to speculate on Butler's biography or draw on her autobiographical accounts; instead, I am interested in the ways Butler's work reflects and mobilizes the personal. As such, Butler does not describe as violent an assignment of Jewishness as Arendt does, and surely, one can assume that her position as a Jewish US citizen implies different relations between her corporeal life and Jewishness.

\footnotetext{
${ }^{3}$ By reading Arendt, Adorno, and Levinas, Butler creates what has been called elsewhere transformative lineage (Rozmarin 2017) - an alternative historical narrative that creates new affective and cultural resources for political transformation. Transformative lineages are created by producing relationships with people, texts, and places that constitute a sense of a past, which poses a political and ethical horizon toward which one can aspire. These intensive affective attachments to the past open the present as a field of multiple paths for action, filled with options for deviating from the hegemonic obvious.
} 
This difference suggests that belonging can be inscribed on one's body by practices of surveillance, discrimination, and violence. However, as I suggested earlier, collective belonging can become rooted in one's bodily being through habits, everyday practices, intonations, and memories of past generations with whom one shares intimate relations as well.

Moreover, belonging can be crafted into a political obligation through critical involvement. Butler's discussion is shaped in relation to two historical events of dispossession and exile. The first is the holocaust from which Arendt fled, which has served as the final justification for the necessity of a Jewish state as a 'national home for the Jewish people.' This led to the second event, the massive dispossession of the Palestinians of their lands during the 1948 and 1967 wars and the continuous denial of their political, human, and civil rights. Butler's engagement with the faith of the people who live in Israel-Palestine and their political history is engendered through critical practices of acquiring diverse and situated knowledge about the conflict. Butler discusses in detail specific aspects and events of the Israeli occupation of the West Bank, and addresses Israeli research on the history and sociology of Zionism. This line of writing delves deeply into the events in Israel-Palestine. It is not purely intellectual or rationality-based judgement; it shows deep emotional commitment and attachment to the people who cohabit this piece of land. Belonging, as shown in the text, stems from continual engagement with a place and the reality of the people who live in it.

Butler's acute critique does not aim to deny the various connections Butler has to Israel-Palestine, to the reality of the people who live there, and to the Jewish tradition. Instead, it affirms the unwilling (yet possibly deniable) belonging as a condition for critique. She affirms her ethical and political position by articulating details of the history of the conflict and the Jewish intellectual heritage of her position.

Hence, Butler's critique shows that pluralization as a principle of collective political subjectivity should not lead to a continual disintegration of historical collectives. Pluralization means continual self-crafting by developing new attachments that transform the political subject, individual, and collective.

\section{Critique and Belonging - Conclusions}

For Butler, belonging is a socio-ontological fact. As corporeal social and relational creatures, we are born in a place shared with others, and we need a place in which social and material conditions can sustain our lives. We are dependent on others, a normative code, and institutions to grant us the status of a human subject who is permitted to participate in the social sphere as political subjects. Ethical and political commitment to plurality stems from the realization that belonging to a place and to the community that inhabits this space is a precondition for our political subjectivity.

Belonging to a group or a place becomes rooted in one's bodily being through the normative practices, which can be violent or discriminatory, that ascribe meaning to bodies. Moreover, belonging becomes a fact rooted in one's body through habits and affective imprints such as sounds, intonations, smells, and memories shared with others. These affective imprints, embodied experiences, and emotions, which are accumulated through encounters with others, create a multi-layered sense of being part of a collective beyond one's choice. As these affective and emotional relations hold the everyday experiences of a group or community, they can be created even in conditions of discrimination and violence, and they can become a cultural resource for political struggle against power formations that deny people the right to live in the place to which they belong. Butler's critical involvement with the Israel-Palestine reality demonstrates how one can become deeply involved by creating critical engagement with the history and reality of a place. 
I argued that regarding cohabitation as multiple affective and emotional ties to a place could contribute to the effectivity of the politics of cohabitation by adding an affirmative aspect to the notion of cohabitation. In relation to the hegemonic association of belonging with the ability to own and control one's home, the notion of cohabitation may be experienced by many as a limitation and potentially as a risk and a loss. A notion of belonging that emphasizes the affective and emotional ties with a place can be an alternative resource to replace the phantasy of owning a space. As such, it may offer a productive alternative to the violent mobilizations of affects as part of hegemonic power formations.

The relations between critique and belonging in Parting Ways offer new insights into a new notion of critique. Butler proposes that critique is an action performed by corporeal subjects in the social sphere. As such, it depends on plurality and cohabitation as an ontological basis. Belonging, in terms of sharing a place with others, offers to critique an affirmative stance the commitment to safeguard the common conditions for a livable life.

As a political act, critique should manifest its dependency on the plurality of the critical position. Belonging is not the limit of critique; it is its condition of possibility. Therefore, part of the goal of critical acts is not to destroy or otherwise hurt the plurality of the political community in relation to which critique is performed. Although the negative part of critique may aim to abolish unjust or oppressive power formations, actions, and ideas, from the perspective of cohabitation, the critical act should affirm the commitment to the pluralization of the political community. Rather than assuming a clear distinction between those who are 'part of the problem' and those who are 'awake' and know the truth, critique is committed to maintaining an open and free social space for thinking and speaking in which no one owns the truth or the space in which people can argue for what they consider to be important or just. One's adversaries, even ideological enemies, are, in fact, crucial for creating a political arena that does not lead to dehumanization and violence. Therefore, the critical subject cannot or should not strive to eliminate radically different positions and beliefs. One can hope to convince others, but not to eradicate from the discussion or the political sphere.

This means that the wish that social discourse will be a safe space in which one is protected from any harm that may be caused by the positions and beliefs of others cannot be defended if safety means being able to preemptively control the kind of positions that can be heard.

For Butler, being part of the collective while also criticizing it means that the critical subject is never a completely unified voice. Instead, the critical subject is in continual conversation and engagement with various others who are part of the subject's embodied sense of belonging.

Moreover, the commitment to promote pluralization also entails that the categories with which one argues for the pluralization of discourse, for example, gender, race, or nationality, should be dynamic and plural to avoid becoming sites of unquestionable conditions of belonging.

Lastly, critique cannot be equated with the mapping of power. Although normative discursive conditions mobilize power by forming the boundaries of livability and precarity, the value and meaning of critical utterances cannot be reduced to their position in relation to normative power. In fact, as a political practice, critique is also obligated to affirm the human conditions of cohabitation and asses its effects in relation to this normative goal.

I believe that this notion of critique is immensely productive for thinking about political lives. In many cases, people are involved in political struggles (be they feminist, anti-racist, or pro-democratic), which fight power structures that shape the spaces, identities, and communities to which they are deeply attached, as well as their memories, relationships, and bodies. Denying the way these forms of power are embedded in different aspects of one's life 
or aspiring to be completely beyond the grip of those structures we aim to change would lead to a simplistic and unsustainable model for political lives in which these relations with the world would appear as a failure. Integrating a sense of critique and belonging might enable us to realize that critique is a continual political action one undertakes with others, not only those who agree with us, but also those whose positions are radically different, and with whom we are destined to share the world.

\section{Funding Information}

This research was supported by the ISRAEL SCIENCE FOUNDATION (grant No. 2540/20).

\section{Competing Interests}

The author has no competing interests to declare.

\section{References}

Adorno, Theodore W. 1973. Negative Dialectics. Translated by E. B. Ashton. New York: Seabury Press.

Allen, Amy. 2016. The End of Progress: Decolonizing the Normative Foundations of Critical Theory. New York: Columbia University Press. DOI: https://doi.org/10.7312/alle17324

Arendt, Hannah. 1951. The Origins of Totalitarianism. Orlando: Harcourt Brace Jovanovich.

Arendt, Hannah. 1958. The Human Condition. Chicago: Chicago University Press.

Arendt, Hannah. 1971. The Life of the Mind. New York: Harcourt Brace.

Asad, Talal. 2003. Formations of the Secular: Christianity, Islam, Modernity. Stanford: Stanford University Press.

Askins, Kye. 2015. 'Being Together: Everyday Geographies and the Quiet Politics of Belonging.' ACME: An International E-Journal for Critical Geographies 14(2): 461-69.

Benhabib, Seyla. 2018. Exile, Statelessness, and Migration. Princeton; Oxford: Princeton University Press. DOI: https://doi.org/10.23943/princeton/9780691167251.001.0001

Birmingham, Peg. 2018. 'Superfluity and Precarity.' Philosophy Today 62(2): 319-35. DOI: https://doi.org/10.5840/philtoday201865217

Butler, Judith. 1993. Bodies That Matter: On the Discursive Limits of "Sex." New York: Routledge.

Butler, Judith. 1997. The Psychic Life of Power: Theories in Subjection. Stanford: Stanford University Press.

Butler, Judith. 2001. 'Giving an Account of Oneself.' Diacritics 31(4): 22-40. DOI: https://doi. org/10.1353/dia.2004.0002

Butler, Judith. 2004a. Precarious Life: The Powers of Mourning and Violence. London: Verso.

Butler, Judith. 2004b. Undoing Gender. London and New York: Routledge. DOI: https://doi. org/10.4324/9780203499627

Butler, Judith. 2012. Parting Ways: Jewishness and the Critique of Zionism. New York: Columbia University Press.

Butler, Judith. 2015. Notes Toward a Performative Theory of Assembly. Cambridge, MA: Harvard University Press. DOI: https://doi.org/10.4159/9780674495548

Butler, Judith, and Athena Athanasiou. 2013. Dispossession: The Performative in the Political. Cambridge, UK: Polity Press.

Butler, Judith, and Gayatri Chakravorty Spivak. 2007. Who Sings the Nation-State? Language, Politics, Belonging. Oxford: Seagull Books.

Culbertson, Carolyn. 2013. 'The ethics of relationality: Judith Butler and social critique.' Continental Philosophy Review 46: 449-463. DOI: https://doi.org/10.1007/s11007-013-9271-z

Horkheimer, Max. 2004. Eclipse of Reason. London: Continuum Press. 
Jaeggi, Rahel. 2018. Critique of Forms of Life. Translated by Ciaran Cronin. Cambridge, MA: Belknap Press/Harvard University Press.

Kellogg, Catherine. 2018. 'Butler's Arendt: Dispossession and the Calamity of the Rightless.' Philosophy Today 62(2): 357-76. DOI: https://doi.org/10.5840/philtoday2018522215

Klee, Louis, and Anya Topolski. 2018. 'Parting Ways or Ways to Cohabitation: Introduction.' The European Legacy 25(3): 237-47. DOI: https://doi.org/10.1080/10848770.2020.1741 261

Kohl, Ellen. 2020. “Some We's Weren't Part of We': Intersectional Politics of Belonging in U.S. Environmental Justice Activism.' Gender, Place \& Culture. AHEAD-OF-PRINT, 1-21. DOI: https://doi.org/10.1080/0966369X.2020.1832968

Lederman, Shmuel. 2020. 'Parting Ways Too Soon: Arendt Contra Butler on Zionism.' The European Legacy 25(3): 248-65. DOI: https://doi.org/10.1080/10848770.2020.1741262

Loidolt, Sophie. 2018. Phenomenology of Plurality: Hannah Arendt on Political Intersubjectivity. New York: Routledge. DOI: https://doi.org/10.4324/9781315208565

Mahmood, Saba. 2003. 'Ethical Formation and Politics of Individual Autonomy in Contemporary Egypt.' Social Research: An International Quarterly 70(3): 837-66.

Mahmood, Saba. 2005. Politics of Piety. The Islamic Revival and the Feminist Subject. Princeton: Princeton University Press. DOI: https://doi.org/10.1017/UP09781580466301

Mahmood, Saba. 2006. 'Human Rights and State Violence.' Anthropology News 47(6): 8. DOI: https://doi.org/10.1525/an.2006.47.6.8

McNay, Lois. 2014. The Misguided Search for the Political. Cambridge, UK: Polity Press.

Pulkkinen, Tuija. 2018. 'Judith Butler's Politics of Philosophy in Notes toward a Performative Theory of Assembly-Arendt, Cavarero, and Human 'Appearing' and 'Plurality." Redescriptions: Political Thought, Conceptual History and Feminist Theory 21: 47. DOI: https://doi. org/10.7227/R.21.2.3

Rebughini, Paola. 2018. 'Critical Agency and the Future of Critique.' Current Sociology 66(1): 3-19. DOI: https://doi.org/10.1177/0011392117702427

Rozmarin, Miri. 2017. Vulnerable Futures, Transformative Pasts: On Vulnerability, Temporality, and Ethics. Oxford: Peter Lang. DOI: https://doi.org/10.3726/b11209

Yuval-Davis, Nira, Kalpana Kannabiran, and Ulrike Vieten. (eds.) 2006. The Situated Politics of Belonging. London: Sage Publications.

How to cite this article: Rozmarin, Miri. 2021. "Critical Belonging: Cohabitation, Plurality, and Critique in Butler's Parting Ways." Redescriptions: Political Thought, Conceptual History and Feminist Theory 24(1): 27-41. DOl: https://doi.org/10.33134/rds.340

Submitted: 23 October 2020 Accepted: 09 June $2021 \quad$ Published: 22 July 2021

Copyright: (c) 2021 The Author(s). This is an open-access article distributed under the terms of the Creative Commons Attribution 4.0 International License (CC-BY 4.0), which permits unrestricted use, distribution, and reproduction in any medium, provided the original author and source are credited. See http://creativecommons.org/licenses/by/4.0/.

Redescriptions: Political Thought, Conceptual History and

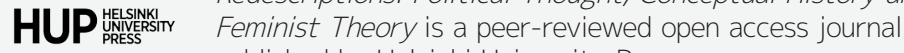
published by Helsinki University Press. 